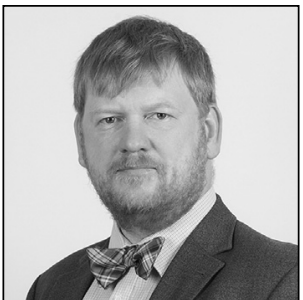

Andres Parmas

Judge, Tallinn Circuit Court

Assistant of Criminal Law

University of Tartu

\title{
Superior Responsibility in Estonian Criminal Law and its Compliance with International Law"
}

\section{Introduction}

The concept of superior responsibility, or command responsibility, is an original creation of international law that has no exact counterpart in domestic legal systems. ${ }^{{ }_{2}}$ As superior responsibility has been regulated in detail in Art. 28 of the Rome Statute, it is crucial to analyse the accordance of domestic rules with this, because states parties to the Rome Statute have a strong incentive to bring their domestic law into compliance with that statute so as to effectuate the complementarity principle under which the International Criminal Court is acting. ${ }^{*} 3$

In this article, I will firstly give an overview of the state of international law on the responsibility of the superior (both in customary international law and in respect of the Rome Statute). With this grounding, the respective regulation of the Estonian Penal Code is outlined. Further discussion assesses whether and in what respect the Estonian regulation differs from international law and what legal consequences such difference would bring about. On the basis of this assessment, I will propose some amendments to Estonian regulation of the responsibility of the superior.

\section{The responsibility of the superior in international law}

The doctrine of superior responsibility crystallised in customary international criminal law soon after the Second World War. ${ }^{* 4}$ Although neither the statute for International Military Tribunal use nor that of the International Military Tribunal for the Far East (IMTFE) contained a specific provision on superior

1 The research for this article was conducted in the Law Faculty of Georg-August-University of Göttingen and supported through partnership agreement between University of Tartu and Georg-August-University of Göttingen.

2 R. Cryer et al., An Introduction to International Criminal Law and Procedure (3rd ed., Cambridge University Press 2014), p. 384. - DOI: https://doi.org/10.1017/CBO9781107588707.

3 Holding this view are, for instance, R. Cryer et al. (ibid.), p. 81.

4 A. Cassese, Cassese's International Criminal Law (3rd ed., OUP 2013), p. 186. - DOI: https://doi.org/10.1093/ he/9780199694921.001.0001. 
responsibility, the concept already was being utilised during the criminal proceedings against war criminals in the immediate aftermath of World War II. The first judgment based on the superior responsibility doctrine was the conviction of Japanese general Yamashita by the US military tribunal in Manila. ${ }^{*}{ }_{5}$ Later, the doctrine was invoked in several trials before the US military courts in Nuremberg ${ }^{* 6}$ but also in the IMTFE in Tokyo and in a number of British, Canadian, Australian, and Chinese war crimes trials as documented by the United Nations War Crimes Commission (UNWCC). ${ }^{*} 7$ The first international agreement to regulate the criminal responsibility of superiors was Additional Protocol I to the 1949 Geneva Conventions, Art. 86 (2). ${ }^{* 8}$ The statute both of the International Criminal Tribunal for the Former Yugoslavia (ICTY) and of the International Criminal Tribunal for Rwanda (ICTR) contained a provision on the responsibility of superiors ${ }^{*}$, and both ad hoc tribunals have applied the elements of the doctrine and explained the scope of these in numerous cases. ${ }^{*} 10$

The ICTY and ICTR jurisprudence have established that three elements must be satisfied if a superior is to be held responsible under the doctrine of superior responsibility: 1) the existence of a superior-subordinate relationship must have been established, 2) the superior knew or had reason to know that the criminal act was about to be or had been committed, and 3) the superior failed to take the measures necessary and reasonable to prevent the criminal act or punish the perpetrator thereof. ${ }^{*} 11$

Still, before adoption of the Rome Statute several aspects of superior responsibility remained hazy. As $\mathrm{K}$. Ambos has put it, notwithstanding the increasing application of the doctrine since the Second World War, its elements have not been defined precisely enough to be indubitably in accordance with the nullum crimen principle as laid down in the Rome Statute, especially with its requirement of legal exactness and strictness. ${ }^{*} 12$ With Art. 28 of the Rome Statute, the doctrine has been refined considerably in an effort to overcome these issues.

As articulated by the language of Art. 28, the actus reus of superior responsibility is composed of five elements: 1) The perpetrator is either a de iure or de facto military or civilian superior who has forces or subordinates subject to his or her command; any kind of superior and subordinate relationship would seem to be sufficient. 2) The military commander has command or, alternatively, authority and has control, whereas the civilian superior has authority and control over the subordinates, and this command or authority and this control must be effective. The civilian superior must, in addition, have effective responsibility for the activities that led to the crimes committed, along with control over those activities. 3) The crimes committed by the subordinates are a result of the superior's failure to exercise proper control over them.

5 Consider the case Yamashita, US Military Commission, Manila (8 October - 7 December 1945), and the Supreme Court of the United States (judgments delivered on 4th February 1946). Available at: UNWCC, Law Reports of Trials of War Criminals, Vol. IV, p. 1 et seq.

6 See discussion of US $v$. Brandt et al. in 'Nürnberg Military Tribunals under Control Council Law No. 10', in Trials of War Criminals, Vol. II, p. 171, at pp. 212, 213; US v. von List et al. in 'Nürnberg Military Tribunals under Control Council Law No. 10', in Trials of War Criminals, Vol. XI, p. 1230, at pp. 1256-1257; US v. von Leeb et al. in 'Nürnberg Military Tribunals under Control Council Law No. 10', in Trials of War Criminals, Vol. XI, pp. 462-697, at p. 489.

7 See the more thorough discussion by K. Ambos: 'Superior Responsibility', in A. Cassese, P. Gaeta, J.R.W.D. Jones (eds), The Rome Statute of the International Criminal Court: A Commentary, Vol. 1 (OUP 2002), pp. 810-813. - DOI: https:// doi.org/10.1093/law/9780198298625.001.0001. Cf. W.H. Parks, 'Command Responsibility for War Crimes', Military Law Review 62 (1973), p. 2, at p. 69 et seq.; G. Werle, F. Jessberger, Völkerstrafrecht (4th ed., Mohr Siebeck 2016), para 606.

8 Art. 86 (2) stipulates criminal responsibility for the superior's failure to act: 'The fact that a breach of the Conventions or of this Protocol was committed by a subordinate does not absolve his superiors from penal or disciplinary responsibility, as the case may be, if they knew, or had information which should have enabled them to conclude in the circumstances at the time, that he was committing or was going to commit such a breach and if they did not take all feasible measures within their power to prevent or repress the breach.' Protocol Additional to the Geneva Conventions of 12 August 1949, and relating to the Protection of Victims of International Armed Conflicts (Protocol I), 8 June 1977. Available at https://ihl-databases.icrc. org/applic/ihl/ihl.nsf/Article.xsp?action=openDocument\&documentId=043A5B6666FA92E6C12563CD0051E1E7, last visited on 23.3.2019.

9 See Art. 7(3) of the ICTY Statute and Art. 6(3) of the ICTR Statute.

10 See, especially, the judgment in Prosecutor $v$. Delalic et al., IT-96-21-T, T.Ch., 16.11.1998, para 330 et seq.; judgment in Prosecutor v. Aleksovski, IT-95-14/1, T.Ch., 25.6.1999, para 66 et seq.; judgment in Prosecutor v. Orić, IT-03-68-T, T.Ch., 30.6.2006, para 289 et seq.; judgment in Prosecutor v. Halilović, IT-01-48, T.Ch., 16.11.2005, para 38 et seq.; judgment in Prosecutor v. Perišić, IT-04-81-T, T.Ch., 6.9.2011, para 1651 et seq.; judgment in Prosecutor v. Kayishema and Ruzindana, ICTR-95-1, T.Ch., 21.5.1999, paras 208 et seq., 473 et seq.; judgment in Prosecutor v. Nahimana et al., ICTR-99-52-T, T.Ch., 3.12.2003, para 970 et seq.

11 See, with extensive reference to older case-law, Halilović (ibid.), para 56.

12 K. Ambos, 'Superior Responsibility' (see Note 6), p. 829. 
4) The superior fails to take the necessary and reasonable measures within his or her power against the crimes committed. 5) The countermeasures are taken with an aim of preventing or repressing the commission of the crimes, or the superior has to submit the matter to the competent authorities for investigation and prosecution. ${ }^{*} 13$

According to Art. 28 of the Rome Statute, the objective elements of superior responsibility have to be accompanied by sufficient mens rea with respect to the circumstances of the actus reus, which may come about in the following forms: either 1) both military commander and civilian superior had knowledge or 2) the military commander had to know, 3) or the civilian superior consciously disregarded information clearly indicating that the subordinates were committing or about to commit such crimes. Hence, the Rome Statute expressly lowers the mens rea standard below the one generally set by Art. 30 for superiors. There is ambiguity as to what concrete mental standard is to be applied to civilian superiors, while with regard to military superiors the standard seems to be negligence. ${ }^{*} 14$

With the above borne in mind, we can now proceed to outline the elements of the superior responsibility concept as addressed by the Estonian Penal Code.

\section{Superior responsibility under the Estonian Penal Code}

In the Estonian Penal Code (PC), the concept of superior responsibility has been regulated in a manner considerably different from that articulated by the corresponding rules of international law. ${ }^{*} 5$ According to Art. 88 (1) of the PC, for a criminal offence covered by Chapter 8 (offences against humanity and international security), the representative of state power or military commander who issued the order to commit the criminal offence, who consented to commission of the criminal offence or failed to prevent the commission of the criminal offence although it was in his or her power to do so, or who failed to submit a report of a criminal offence while being aware of the commission of the criminal offence by his or her subordinates shall be punished in addition to the principal offender. From the above it can be concluded that Art. 88 (1) encompasses the core elements presented below.

\subsection{The language 'for the criminal offence provided for in this chapter'}

Whilst the concept of superior responsibility in the Rome Statute only covers the four so-called core crimes $^{*}{ }^{*}$, Estonian regulation goes further. Chapter 8 of the PC provides for definition of other than 'core' crimes also, additional crimes possessing an international element. With Art. 92, propaganda for war and with Art. $93^{1}$ failure to apply international sanctions are criminalised. The same applies for piracy, via Art. 110; hijacking of aircraft, under Art. 111; and attacks against flight safety, with Art. 112.

\subsection{The element 'shall also be punished in addition to the principal'}

It is noteworthy that for the whole palette of criminal offences covered by Chapter 8 of the PC and also for the entire spectrum of criminal omissions attributable to the superior, the superior shall be punished in line with the same norm as the principal offender. This is a very broad foundation for responsibility, far

13 K. Ambos, Der Allgemeine Teil des Völkerstrafrechts. Ansätze einer Dogmatisierung (Duncker \& Humblot 2002), pp. 705-706; K. Ambos, Treatise on International Criminal Law, Vol. I: Foundations and General Part (OUP 2013), p. 207. - DOI: https:// doi.org/10.1093/law/9780199657926.001.0001.

14 G. Werle, F. Jessberger, Völkerstrafrecht (see Note 6), paras 622-623.

15 For a similar assessment, see H. B', in A. Eser, H. Kreicker, U. Sieber (eds), Nationale Strafuerfolgung völkerrechtlicher Verbrechen. Band 7 (Duncker \& Humblot 2006), p. 236.

16 R. Arnold, O. Triffterer, 'Article 28: Responsibility of Commanders and Other Superiors', in O. Triffterer, K. Ambos, Rome Statute of the International Criminal Court: A Commentary (C.H. Beck, Hart, Nomos 2016), para 81; G. Werle, F. Jessberger, Völkerstrafrecht (see Note 6), para 603. 
surpassing the general rules on an accomplice's responsibility as foreseen in Art. 22 or $22^{1}$ of the PC. Even in cases wherein the role of the superior would not even suffice for said person being punishable as an accomplice under Art. 22 of the PC, the superior is still liable through Art. 88 (1), without there even being a chance of mitigation of punishment as provided for in Art. 22 (5) and Art. 60 of the PC. This means also that a superior might be liable for a subordinate's act where a certain minimum standard must be met for mens rea on his or her subordinate's part (deliberate intent, dolus directus of the first degree, or direct intent, dolus directus of the second degree) while said superior does not actually share the same level of mens rea and acts only with indirect intent (dolus indirectus).

\subsection{The 'military commander' reference}

The language used in Art. 88 (1) of the PC is perplexing in the manner in which it specifies which types of superiors are encompassed by this regulation. From the text it is obvious that the definition covers military commanders. It is also clear that the authority of the military commander does not have to be official - the wording 'the representative of state powers or the military commander' is sufficient to cover persons who have de iure military authority in any armed forces representing a government but also extends to persons commanding armed groups that do not owe allegiance to any government - e.g., forces of mutineers beyond government control or even non-governmental armed groups (militias etc.). It is noteworthy also that the term 'military commander' is broad enough to cover not only persons belonging to a fixed pre-determined military hierarchy and formally occupying a position of superiority in such a hierarchy; the concept of military commander must be considered to extend also to someone exercising de facto military authority over others, without any formal commanding position. ${ }^{* 17}$ This is especially important to bear in mind in conjunction with the options of guerrilla warfare (of which Estonia already has historical experience, from the 1940s-1950s) and spontaneous armed resistance addressed in Art. 54 (2) of the Estonian Constitution. ${ }^{*} 18$ What matters is that the person concerned has people actually effectively perceiving themselves as subordinate to him or her.

\subsection{Application to a non-military representative of state power}

As for non-military superiors, it appears that only a very limited set of formal superior-subordinate relationships is covered by Art. 88 (1) of the PC. This is obvious from the wording 'representative of state powers'. It cannot be imagined that someone who acts as a representative of state authority (i.e., has a formal position and is vested with formal functions and authority stemming from the position he or she occupies) could at the same time function also as a representative of state power outside this position and hence in relationship with persons not formally subject to him or her by dint of that formal position. ${ }^{*} 9$ Likewise, it can be ruled out that anyone could function as a representative of state power outside formal state structures. Hence, people such as influential businessmen, politicians, clergymen, or representatives of NGOs, who might be able to effectively control and direct others but who do not occupy any formal position in the state structure, clearly fall outside the regulation of Art. 88 (1). Another conclusion one has to draw from the text of Art. 88 (1) is that people representing public authority on behalf of anything that is not strictly of a state nature cannot be held responsible through application of the concept of a superior's orders, at least according to Art. 88 (1). This means that, amongst other things, actions of municipal officers too are excluded from the regulation's ambit. ${ }^{*} 20$

17 J. Tehver, '§ 88', in J. Sootak, P. Pikamäe (eds), Karistusseadustik. Kommenteeritud väljaanne (Penal Code. Commented Edition) (4th ed., Juura 2015), para 3.

18 According to Art. 54 (2) of the Estonian Constitution, in the absence of other means, every citizen of Estonia has the right to resist, of his or her own initiative, a forcible attempt to change the constitutional order of Estonia. This entitlement could bring about spontaneously organised groups that operate under the informal authority and control of a de facto superior without any formal position.

19 Imagine, for instance, a member of government who also owns a factory where prisoners of war are treated inhumanely by the management with his or her acquiescence.

20 See a similar conclusion by J. Tehver, ‘§ 88’ (see Note 16), para 2. 


\subsection{The phrasing 'issued the order to commit the criminal offence'}

In Art. 88 (1), the concept of superior responsibility has been intermingled with the direct responsibility of principal offenders and criminal responsibility of accomplices: in this article of law, active and passive behaviour are dealt with together. In Estonian criminal-law doctrine, issuing an order to commit a criminal offence might refer to any of the following, depending on the facts of the case: 1) joint commission of an offence, 2) commission of an offence by taking advantage of another person, and 3) inducement to commit an offence. ${ }^{* 21}$ Hence, it seems that with regard to superiors' participation in criminal offences as addressed in Chapter 8 of the Penal Code, the legislator has made an exception to the principle of maintaining this distinction, otherwise followed in Estonian criminal-law doctrine.

\subsection{The element 'failed to prevent the commission of the criminal offence although it was in his or her power to do so or who failed to submit a report of a criminal offence while being aware of the commission of the criminal offence by his or her subordinates'}

In contrast against the alternatives of issuing an order or consenting, for the alternative of failing to prevent there is an additional element foreseen by Art. 88 (1) of the PC: actual control by the superior. The superior is deemed responsible for his or her failure to prevent commission of a criminal offence by subordinates only when it was in his or her power to do so. At the same time, no proof of the superior's power to act is required in connection with criminalisation of failure to submit a report on a criminal offence committed by one's subordinates. For neither of these alternatives, however, is it requisite by law that the superior have had the ability to act or that the superior have been in breach of his or her duties. Neither does the PC make provision for the enhanced risk of subordinates' commission of a criminal offence that emerges from the superior's omission of his or her duty of control.

\subsection{Restriction to intentional behaviour - 'fails to prevent when in his power' and 'failed to submit when aware'}

With regard to mens rea, only intentional conduct seems to be covered by Art. 88 (1) of the PC. According to Art. 15 (1), only an intentional act is punishable unless the Penal Code dictates punishment for an act of negligence. This means that, for an act to be punishable if committed negligently, the legislator has to express said intent explicitly. This has not been done in Art. 88 (1) of the PC. Moreover, for the last alternative, the scenario of non-reporting of a crime already committed, there is punishability only if the non-reporting occurs while the superior is aware of the commission of a crime. Such a standard implies dolus directus of the second degree.

\section{Conflict between the Estonian Penal Code and international criminal law}

Comparing international criminal law on superior responsibility with Estonia's corresponding domestic norms, it appears that in several important respects Estonian law either directly contradicts international law or at least remains very unclear and ambiguous.

Of course, how far to stretch criminal responsibility is always a legal-policy choice - whether to extend it beyond what is necessary for fulfilling the international obligations of the country or, instead, domestically

21 If a superior gives an order to a subordinate to commit an international crime and that subordinate does not have a realistic opportunity to refuse to follow it or at least to challenge or question such an order and therefore obeys the order, it would be correct to consider the superior to be the perpetrator, who commits the offence by taking advantage of the other person. If, however, a superior orders a subordinate to commit an international crime and that subordinate does have a realistic opportunity to refuse execution or at least to challenge or question such an order but obeys the order nevertheless, the act of the superior might be considered inducement. If the execution of the order in such a case is dependent on real-time guidance or instructions by the superior, the superior might as well be regarded as a co-perpetrator along with the subordinates actually executing the order. 
restrict that responsibility relative to international rules. ${ }^{* 22}$ In any case, the decision to deviate from the international standard - whether in expanding or restricting criminal responsibility - should at least be consciously made. As far as the many deviations from international law that are found in Art. 88 (1) of the $\mathrm{PC}$ are concerned, it seems, however, that this is not a result of conscious choice but more a misinterpretation of international obligations. This could be concluded, inter alia, already from the fact that the commentary on the PC refers to the Rome Statute (RS) as the legislator's role model. ${ }^{* 3}$

The present state of Estonian law regarding superior responsibility is problematic, because our current regulation addressing this doctrine does not enable Estonia to adhere to the respective international regulations, especially the requirements of Art. 28 of the Rome Statute. Hence, Estonia's ability to honour the complementarity principle set forth by the International Criminal Court (ICC) is at stake. More specifically, the problems with Art. 88 (1) lie in the following issues.

\subsection{Reference to not only state representatives but all persons with authority (both de iure and de facto)}

Firstly, it appears that Art. 88 (1) of the PC deviates considerably from international law, in establishing the categories of superiors who may be held responsible for the criminal offences committed by subordinates of theirs. According to Art. 28 of the RS, military and non-military superiors alike carry responsibility for their subordinates' crimes if, acting with the requisite mens rea, they fail to exercise control properly over their subordinates and, because of that, fail to take measures in order to prevent, repress, or report the crimes of those subordinates. ${ }^{*} 24$ For neither military nor non-military superiors does Art. 28 of the RS impose the restriction that the superior must occupy a formal position of authority. ${ }^{* 25}$ As affirmed also in the practice of the ad hoc tribunals and the ICC, what matters is the actual authority and control of the superior over persons who are subject to him or her. ${ }^{*}{ }^{26}$

In regard of military commanders, it can be said that Art. 88 (1) of the PC recognises the approach by which what counts is the actual authority and control over subordinates and not the formal position of the commander. The narrowing by which the responsibility of non-military superiors is restricted only to representatives of state power, however, finds no parallel in international law. ${ }^{* 7}$ On the contrary, there is a considerable body of case-law from the ICTY and ICTR whereby the concept of superior responsibility has been applied for non-military superiors. ${ }^{*} 8$ It has been found repeatedly that civilian persons not holding any formal public office can be held responsible as superiors. ${ }^{* 29}$ In fact, already in the Nuremberg follow-up

22 See, for example, H. Kreicker, H. Gropengiesser, 'Deutschland', in A. Eser, H. Kreicker (eds), Nationale Strafverfolgung völkerrechtlicher Verbrechen, Band 1 (Edition-Iuscrim 2003), pp. 298-299, where the author admits that abstinence of the German legislator from criminalising non-reporting of subordinates' crimes when committed negligently could be justified because of the minor legal significance of such violation. See also M. Neuner, 'General Principles of International Criminal Law in Germany', in M. Neuner (ed.), National Legislation Incorporating International Crimes: Approaches of Civil and Common Law Countries (Berliner Wissenschafts-Verlag 2003), p. 130; T. Weigend, 'Zur Frage eines „internationalen“ Allgemeinen Teils', in B. Schünemann et al. (eds), Festschrift für Claus Roxin zum 70. Geburtstag am 15. Mai 2001 (Walter de Gruyter 2001), p. 1375, at p. 1396.- DOI: https://doi.org/10.1515/9783110877021.1375.

23 J. Tehver, '§ 88' (see Note 16), para 1.

24 See R. Arnold, O. Triffterer, 'Responsibility of Commanders' (see Note 15), para 85.

25 G.R. Vetter, 'Command Responsibility of Non-military Superiors in the International Criminal Court (ICC)', Yale Journal of International Law 25 (2000), p. 89, at pp. 117-118 (fn. 171); I. Bantekas, 'The Contemporary Law of Superior Responsibility', AJlL 93 (1999), p. 573, at p. 580. - DOI: https://doi.org/10.2307/2555261; C. Meloni, Command Responsibility in International Criminal Law (T.M.C. Asser Press 2010), p. 159. - DOI: https://doi.org/10.1007/978-90-6704-605-3.

26 I. Bantekas, ibid., p. 582. See also the prosecution's final written submissions on the confirmation-of-charges proceedings, Prosecutor v. Gbagbo, ICC-02/11-01/11-642-Conf, 1.5.2014, paras 26-29 with a further reference to the Decision on Confirmation of Charges, Prosecutor v. Bemba, ICC-01/05-01/08-424, P.T.Ch., 15.6.2009, para 354.

27 See G. Mettraux, The Law of Command Responsibility (OUP 2009), pp. 122-123. - DOI: https://doi.org/10.1093/acprof: oso/9780199559329.001.0001; also W.A. Schabas, The International Criminal Court: A Commentary on the Rome Statute (OUP 2010), pp. 459-460. - DOI: https://doi.org/10.1093/law/9780199560738.001.0001. See also H. Kreicker, H. Gropengiesser, 'Deutschland' (see Note 21), p. 293 ('Vorgesetztenverantwortlichkeit ist nicht nur aufvon Befehl und Gehorsam geprägte militärische Dienstverhältnisse beschränkt, sondern schließt auch sonstige Abhängigkeitsverhältnisse ziviler und faktischer Natur mit ein').

28 On the practice of the ICTY, refer to, for instance, Delalic (see Note 9), para 356; Orić (see Note 9), paras 308-310. For the practice of the ICTR, see the judgment in Prosecutor v. Bagilishema, ICTR-95-1A-A, A.Ch., 3.7.2002, para 51; the judgment in Prosecutor v. Musema, ICTR-96-13-T, T.Ch., 27.1.2000, para 135.

29 For example, see Delalic (see Note 9), para 750; Musema (ibid.), para 880. 
cases, non-military superiors not belonging to a state hierarchy of power (managing physicians and industrialists) were found guilty for reason of superior responsibility. ${ }^{*}{ }^{30}$ Clearly, a formal position in state structures is not the only criterion for a non-military person holding authority over others. Such authority may stem also from a person's position in a municipal power hierarchy and from status in any other hierarchically constructed system but also from informal circumstances. ${ }^{*}{ }^{31}$ The civilian settings wherein superiorsubordinate relationships might give rise to application of the doctrine of superior responsibility could encompass, for instance, organisations with a military-like structure, wherein those in higher positions have effective power to employ physical sanctions against those under them; situations in which a person could be threatened with immediate loss of income or livelihood; and even some religious groups, whose leader may possess strong means of psychological control. ${ }^{*} 2$ Hence, confining the responsibility of civilian superiors under criminal law only to representatives of state power carelessly excludes a whole array of possible string-pullers from responsibility.

That said, a need to limit the set of non-military superiors who shall bear responsibility for their subordinates' crimes is still relevant. Unlike military lines of command, the civilian relationships of subordination are of an extremely varied nature, and there is potential for the according of superior responsibility to become intolerably extensive. ${ }^{*} 3$ One option is for civilian superiors to be held responsible for the acts of their subordinates only if they have a guarantor position - i.e., if the acts of the subordinates fall within the sphere of competence of the superior. ${ }^{*} 34$ Therefore, some kind of restriction to the responsibility of civilian superiors is necessary, but this has to be achieved by other means than narrowing the scope of civilian superior-subordinate relationships under Art. 88 (1) to only those within formal state power hierarchies. In Art. 28 of the Rome Statute, the restriction is handled through an additional requirement, for effective responsibility and control on the superior's part. One of Estonia's options would be to add a similar criterion to Art. 88 (1) of the PC, although domestically the extent of the guarantor responsibility could, alternatively, be constructed without addition of any further elements to the text of the law while this element is left open to judicial assessment. ${ }^{*} 3$

30 See S. Boelaert-Suominen, 'Prosecuting Superiors for Crimes Committed by Subordinates: A Discussion of the First Significant Case Law Since the Second World War', Virginia Journal of International Law 41 (2001), p. 747, at p. 575; also K. Ambos, Der Allgemeine Teil (see Note 12), p. 101. See the respective case-law also: that of the Military Tribunal for the Far East, Judgment of 12 November 1948 (in J. Pritchard and S.M. Zaide (eds), The Tokyo War Crimes Trial, Vol. 22, 49.791); the Government Commissioner of the Judgment on Appeal to the Superior Military Government Court of the French Occupation Zone in Germany, General Tribunal of the Military Government for the French Zone of Occupation in Germany v. Roechling (in Trials of War Criminals before the Nuremberg Military Tribunals under Control Council Law No. 10, Vol. XIV, p. 1097, at p. 1136); United States of America v. Friedrich Flick et al., of 22 December 1947 (in Trials of War Criminals before the Nuremberg Military Tribunal under Control Council Law No. 10, Vol. VI, p. 1187, at p. 1202); United States of America $v$. Karl Brandt et al. (in Trials of War Criminals before the Nuremberg Military Tribunal under Control Council Law No. 10, Vol. II, p. 171, at pp. 193, 198, 207, 212-213).

31 Judgment in Prosecutor v. Akayesu, ICTR-96-4-T, T.Ch., 2.9.1998, para 691 (with the communal bourgmestre as a superior); Musema (see Note 28), para 133 et seq. (with the director of a tea factory as a superior, having effective control over his workers); Flick (see Note 25), para 1202 (with an industrialist as a superior); the judgment in Prosecutor v. Nahimana, ICTR-99-52-A, A.Ch., 28.11.2007, paras 798-822 (with a radio station's de facto boss who did not hold an official position at the station as a superior to the journalists at the station).

32 For instance, see T. Weigend, '§ 4', in W. Joecks et al. (eds), Münchener Kommentar zum Strafgesetzbuch: StGB Band 8: Nebenstrafrecht III, Völkerstrafgesetzbuch (3rd ed., C.H. Beck 2018), para 38.

33 T. Weigend, 'Bemerkungen zur Vorgesetztenverantwortlichkeit im Völkerstrafrecht', ZStW 116 (2004), p. 999, at p. 1011. DOI: https://doi.org/10.1515/zstw.2004.116.4.999.

34 J. Bülte, Vorgesetztenverantwortlichkeit im Strafrecht (Nomos 2015), p. 483. - DOI: https://doi.org/10.5771/ 9783845257969. See also T. Wu, Y. Kang, 'Criminal Liability for the Actions of Subordinates: The Doctrine of Command Responsibility and Its Analogues in United States Law', Harvard International Law Journal 38 (1997), p. 272, at p. 295; also R. Arnold, 'Article 28: Responsibility of Commanders and Other Superiors', in O. Triffterer (ed.), Rome Statute of the International Criminal Court - Observers' Notes, Article by Article (2nd ed., C.H. Beck, Hart, Nomos 2008), para 129. - DOI: https://doi.org/10.5771/9783845263571-1057.

35 There exists no rule in Estonian Law regulating specifically in which instances the person in an official position would be liable for omissions in office (with regard to the guarantor position of the person holding that office). This has to be assessed on a case-by-case basis by the judiciary in accordance with the general rule on omissions (in Art. 13 of the Penal Code). See also the judgment of the Criminal Chamber of the Supreme Court in case 3-1-189-11, para 20.7.3, where the chamber states: 'Karistusõigus ei võimalda omistada ühe füüsilise isiku tegu teisele füüsilisele isikule pelgalt nende isikute ametiseisundi alusel', in translation 'It is not possible in penal law to attribute an act of one physical person to another physical person on the basis merely of the official position of such persons'. Available at https://www.riigikohus.ee/et/lahendid?asjaNr=3-1-1-89-11, last visited on 12.2.2019. By way of analogy, the domestic court could also assess the relationship between a civilian superior and his or her subordinate. 


\subsection{The order to commit a crime (direct responsibility) vs. consent: Non-prevention and non-repression (superior's responsibility)}

By the doctrine, having superior responsibility is, in essence, sui generis ${ }^{*}{ }^{6}$ grounds for liability in addition to ordinary grounds for liability - those applied to principal offenders or to accomplices. The superior is answerable as a guarantor for not having taken any - or at least not having taken the necessary and reasonable - measures to avoid criminal offences on his or her subordinates' part. Hence, this is a responsibility for omission (a real omission). ${ }^{*} 37$ In one line of jurisprudence, it has been treated as responsibility of the superior for the crimes committed by subordinates, whereas another approach has been to treat the offence separately as an instance of the superior's dereliction of his or her duty to supervise the relevant subordinates properly. ${ }^{*} 38$ Recent legal thought has shown clear support for the latter approach. ${ }^{*} 39$ Either way, it is clear from both the law and jurisprudence that there exists a clear distinction between the personal liability for the criminal offences committed by the person or at least aided and abetted by that person and, on the other hand, the extended liability accorded to the superior because of what has, in fact, been done by anoth er person or because of dereliction of duty by the superior. ${ }^{*} 40$ This distinction has been lost with Art. 88 (1) of the PC. Issuing an order to commit a crime is not an omission; rather, it constitutes an active behaviour aimed at achieving the criminal end. ${ }^{*} 4$ As stated above (in Subsection 3.5 of this paper), in Estonian criminal law ordering a criminal offence could, under certain conditions, constitute joint commission of a criminal offence or commission of a criminal offence while one is taking advantage of another person.

Similar criticism can be levelled at the handling of the second alternative of the actus reus of superior responsibility in Art. 88 (1) of the $\mathrm{PC}$ - consent to a criminal offence. If consent in a specific case would bring about a situation wherein the superior is not aware of the criminal offence of the subordinate in advance of it or at least wherein the superior does not have specific knowledge of the criminal offence, applying the concept of consent is misplaced, because such behaviour would already be encompassed by the alternative either of failure to prevent the criminal offence or of failure to repress it.

It seems from the above that behaviours of very different nature and of quite different gravity have been muddled together under the umbrella of superior responsibility in Art. 88 (1) of the PC. Overlap between the doctrine of superior responsibility and other grounds for personal criminal responsibility creates a serious question, on which basis one must decide which dogmatic figure to prefer when prosecuting a superior who has issued an order to commit a criminal offence. As responsibility for an active behaviour should, in principle, always have priority over responsibility for an omission, such a normative construction is perplexing at best. ${ }^{*} 42$

36 Halilović (see Note 9), para 78; also G. Werle, F. Jessberger, Völkerstrafrecht (see Note 6), paras 603, 607.

37 H. Kreicker, H. Gropengiesser, 'Deutschland' (see Note 21), pp. 295-296; also K. Ambos, Internationales Strafrecht (5th ed., C.H. Beck 2018), §7, para 55.

38 Y. Ronen, 'Superior Responsibility of Civilians for International Crimes Committed in Civilian Settings', Vanderbilt Journal of Transnational Law 43 (2010), p. 313, at p. 315. For older case-law, upholding the first approach, see, for instance, Akayesu (see Note 30), para 471: 'Article 6(3), by contrast, constitutes something of an exception to the principles articulated in Article $6(1)$, as it derives from military law, namely the principle of the liability of a commander for the acts of his subordinates or "command responsibility", whereas the second approach has been preferred in more recent case-law, with the Halilovic ruling providing an illustration (see Note 9), in para 54: 'The commander is responsible for the failure to perform an act required by international law. This omission is culpable because international law imposes an affirmative duty on superiors to prevent and punish crimes committed by their subordinates. Thus "for the acts of his subordinates" as generally referred to in the jurisprudence of the Tribunal does not mean that the commander shares the same responsibility as the subordinates who committed the crimes, but rather that because of the crimes committed by his subordinates, the commander should bear responsibility for his failure to act.'

39 See, for example, R. Värk, 'Superior Responsibility' ENDC Proceedings 15 (2012), p. 143, at pp. 143-144; but also relevant jurisprudence in: Orić (see Note 9), para 293; also Bemba (see Note 25), para 405. Available at https://www.ksk.edu.ee/ wp-content/uploads/2012/12/KVUOA_Toimetised_15_7_Vark.pdf, last visited on 12.2.2019.

40 For a thorough explanation of this, see K. Ambos, Der Allgemeine Teil (see Note 12), pp. 670-672. See also H. Kreicker, H. Gropengiesser, 'Deutschland' (see Note 21), pp. 292-293.

41 K. Ambos, 'Article 25: Individual Criminal Responsibility', in O. Triffterer, K. Ambos, Rome Statute of the International Criminal Court: A Commentary (C.H. Beck, Hart, Nomos 2016), para 18, with a reference to relevant case-law of the UN SC ad hoc tribunals (fn. 124) and to the ICC (fn. 128). - DOI: https://doi.org/10.5771/9783845263571.

42 H. Kreicker, H. Gropengiesser, 'Deutschland' (see Note 21), p. 294. 


\subsection{The dubious element of effective control}

Another aspect of Estonian regulation that calls for criticism of its handling of superior responsibility is Art. 88 (1)'s inadequate formulation of the condition of effective command (or authority) and control. The idea of military commander and of representative of state power are not enough on their own for determining whether any particular superior had actual power over his or her subordinates. ${ }^{*} 43$ For that, the further elements of command (or authority) and control are necessary. Forces subject to effective command and control are those that are, according to an objective assessment, subordinate to the commander in either a de iure or a de facto chain of command and to which the superior may give orders. ${ }^{*} 44$ The concept of authority may refer to the modality, manner, or nature according to which a military or military-like commander exercise 'control' over the forces or subordinates. ${ }^{*} 5$ Effective control means the material ability to prevent the commission of the offence or to punish the principal offenders. ${ }^{*} 46$

It has been stressed in the case-law that this requirement is not satisfied by simple demonstration of the accused individual's general influence. ${ }^{*} 47$ Therefore, considering both the elements of a superior-subordinate relationship as such and effective control is inevitable. Without effective control or even when it is just too remote, responsibility is excluded. ${ }^{*}{ }^{8}$ Otherwise, we would speak of strict vicarious liability - it is precisely the element of effective control that enables censuring the superior for not having acted. Only the superior position per se in combination with effective power over people subject to one is sufficient for justifying the extension of responsibility to a given superior. ${ }^{*} 49$ In regard of civilian superiors, the requirement of effective control plays a particular role. As a rule, control in civilian hierarchies is less strict than its equivalent in military hierarchies. ${ }^{*} 50$ Therefore, the duty of a civilian superior to control his or her subordinates has to be limited to what 'is part of their relationship. ${ }^{*}{ }^{1}$ This is the reason there exists even further specification of the requirement set in Art. 28 (b) (ii) of the RS for cases of civilian superiors: the crimes had to pertain to activities under the effective responsibility and control of the superior. This specification refers to actual fulfilment of the non-military superior's professional or other relevant functions in relation to his or her subordinates, and it works as a safety clause against presumptions of excessively expansive expectations for the exercise of authority by a non-military superior.

With Art. 88 (1) of the PC, an attempt has been made to formulate the element of effective command (or authority) and control by means of the language 'was in his or her power'. However well-intentioned, this phrasing is not capable of conveying everything that is necessarily encompassed by the concept of effective command/authority and control. Firstly, it remains unclear whether the mention of someone's 'power' is intended to refer to that person's status as a superior. If so, the criticism is obvious - merely the fact that someone has a position of authority (either de iure or de facto) does not necessarily mean that this person is also in any given situation able to actually exercise said authority. The superior might be hindered in this by the subordinates having gone out of control. ${ }^{*}{ }^{2}$ The same is true for a military adviser who has neither operational nor administrative control: advisers are to advise, not 'replace' the commander. ${ }^{*} 3$ If, on the

43 E. v. Sliedregt, Individual Criminal Responsibility in International Law (OUP 2012), pp. 197-198. - DOI: https://doi. org/10.1093/acprof:oso/9780199560363.001.0001. See also K. Ambos, Treatise (see Note 12), pp. 211-212.

44 See R. Arnold, O. Triffterer, 'Responsibility of Commanders' (see Note 15), para 102.

45 See Bemba (see Note 25), paras 414-415.

46 See the Halilović decision (see Note 9), paras 57-59, and also the appeals of the judgment in the same case, IT-01-48-A, A.Ch., 16.10.2007, paras 59, 66. See, with reference to extensive previous case-law of the ICTY and ICTR, Orić (see Note 9), para 311.

47 Judgment in Prosecutor v. Ntagerura, ICTR-99-46-A, A.Ch., 7.7.2006, paras 341-342; judgment in Prosecutor v. Karera, ICTR-01-74-T, T.Ch., 7.12.2007, para 564.

48 Delalic (see Note 9), paras 377, 378; see also I. Bantekas, Principles of Direct and Superior Responsibility in International Humanitarian Law (Manchester University Press 2002), p. 82.

49 R. Cryer et al., Introduction to International Criminal Law (see Note 1), pp. 386-387.

50 W.J. Fenrick, 'Some International Law Problems Related to Prosecutions before the International Criminal Tribunal for the Former Yugoslavia', Duke Journal of Comparative and International Law 6 (1995), p. 103, at p. 117: 'Military commanders do exercise command. They have control over subordinates in a rigid hierarchical system with disciplinary powers and the authority to order subordinates. The scope of this military authority includes the power to order subordinates to risk their own lives. Most bureaucratic leaders do not wield the same type of life and death authority.'

51 T. Wu, Y. Kang, 'Criminal Liability' (see Note 35), p. 295.

52 See K. Ambos, 'Superior Responsibility' (see Note 6), p. 839.

53 J. de Preux, 'Commentary on Articles 86 and 87 of Protocol Additional I', in Y. Sandoz, C. Swinarski, B. Zimmermann (eds), Commentary on the Additional Protocols of 8 June 1988 to the Geneva Conventions of 12 August 1949 (Martinus Nijhoff 
other hand, the reference to 'power' is intended to bring into the picture the actual capability of the superior to take measures against the subordinates, the problem is that a person's practical ability to act says little, if anything, about his or her obligation to act. ${ }^{*} 54$ A person in a superior position cannot be expected to, as it were, carry the burden of the whole world and be wary of each and every violation that people in subordinate position might commit. Factors such as the division of the work and responsibilities among several superiors, delegation of rights and obligations, and rotation of command become important in this connection and have to be evaluated. ${ }^{*} 55$

Hence, a proper reference to effective command (or authority) and control in the text of the law would be vital.

\subsection{Inability to explain why not preventing an offence has to be in the power of the superior while non-reporting need not be - strict liability}

It is likewise inexplicable why a different standard has been chosen for the superior's duty to report a criminal offence as compared to his or her duty to prevent a criminal offence. ${ }^{*}{ }^{6}$ Mere awareness of the criminal offence does not imply that the superior had a chance to submit the relevant report: he or she may not have had the actual material ability to do so, or there may have been nobody to report to. ${ }^{*} 57$ Rather, gaining knowledge of the criminal offence committed or about to be committed is only the first step in several toward meeting the conditions required. The criterion of actual ability to act still must be addressed if one is to decide on extension of liability to the superior. This might be an insignificant problem in most cases, but it is a problem nevertheless. In the international-law doctrine of superior responsibility, all three duties of superiors in respect of crimes of their subordinates - to prevent, to suppress, and to report - are bound to the superior's actual ability to fulfil these duties. ${ }^{*} 8$

\subsection{The absent element of 'failure to exercise control properly over subordinates' and the ambiguity of 'failure to take necessary and reasonable measures'}

It is important to keep in mind that superior responsibility is not a form of strict liability. ${ }^{*} 59$ Nor are the accusations to the superior to be determined from only an ex post perspective during investigation and prosecution; one must assess ex ante - in light of the circumstances as they unfolded - what means and measures and what information were available to the superior. What could the superior have been reasonably expected to do in the situation in which he or she was embedded?*6o Therefore, the not-prevented

1987), para 3557, with its statement that legal advisers are there to 'advise the military commanders' in this field, not to replace them.

54 This issue arises especially with non-military superiors, because the referral to such power does not say anything about their competence as a superior - their professional relationship with the subordinate, which must be the bottom line when one is attributing responsibility to such superiors for the acts of their subordinates. As is pointed out above (see the first part of Section IV), a non-military superior can be made responsible for only that omission that is 'within the effective responsibility and control' of this superior. See R. Arnold, O. Triffterer, 'Responsibility of Commanders' (see Note 15), para 128. See also M.L. Nybondas, Command Responsibility and Its Applicability to Civilian Superiors (T.M.C. Asser Press 2010), p. 86. - DOI: https://doi.org/10.1007/978-90-6704-443-1.

55 See R. Arnold, O. Triffterer, 'Responsibility of Commanders' (see Note 15), para 111; K. Ambos, 'Superior Responsibility' (see Note 6), pp. 840-841.

56 According to Art. 88 (1) of the PC, a superior is responsible for failing to prevent the commission of the criminal offence although it was in his or her power to do so, but failing to submit a report of a criminal offence while being aware of the commission of the criminal offence by his or her subordinates.

57 In this connection, see, for instance, the judgment in Prosecutor $v$. Krnojelac, IT-97-25-T, T.Ch., 15.3.2002, para 127; the judgment in Prosecutor v. Krstic, IT-98-33-A, A.Ch., 19.4.2004, para 143, fn. 250.

58 See R. Arnold, O. Triffterer, 'Responsibility of Commanders' (see Note 15), paras 118, 119.

59 See, for example, Akayesu (see Note 30), paras 488-489.

60 C. Meloni, Command Responsibility (see Note 24), pp. 121-122, 171; see also the judgment in Prosecutor v. Blaškič, IT-9514, A.Ch., 29.7.2004, para 72; the judgment in Prosecutor v. Halilović, IT-01-48-T, A.Ch., 16.10.2007, para 63; the judgment in Prosecutor v. Orić, IT-03-68-A, A.Ch., 3.7.2008, para 177; the judgment in Prosecutor v. Bemba, ICC-01/05-01/08 A, A.Ch., 8.6.2018, paras 167-170. 
criminal offences of the subordinates have to be in a causal relationship with the omission by the superior. ${ }^{*}{ }^{61}$ However, in cases of criminal offences currently being committed or of criminal offences already carried out, the relevance lies not in assessing causality but in enquiring as to whether his or her failure to exercise control properly over subordinate persons increased the risk of commission of the crimes. ${ }^{*}{ }^{2}$ In effect, the Pre-Trial Chamber in the Bemba case has followed the Risikoerhohungstheorie, according to which sufficient conditions are met when the superior's non-intervention has increased the risk of commission of the subordinates' crimes. ${ }^{* 63}$ Although the Pre-Trial Chamber has considered the risk approach to be something completely different from applying the causality theory, this is not actually the case, because the risk approach also constitutes a causality test, in the sense that there is the implication that the increased risk is at least one of the causes of the harmful result. ${ }^{*} 4$

The requirement of properly exercising control over one's subordinates is something that can and must be objectively assessed against the standard behaviour of a similar superior in a similar situation. Hence, a breach of this requirement can only constitute a deviation from such standard behaviour. The requirement of necessary and reasonable measures therefore entails completing an objective assessment of what a reasonable superior would have been expected to do in a situation similar to that represented by the facts of the case. Again, failure to take such measures can only be a deviation from the standard of reasonable actor. ${ }^{* 65}$

Regrettably, in Art. 88 (1) of the PC these requirements have been completely overlooked. The practical implications that this might have for prosecution of superiors under Art. 88 (1) are huge. Consider, for example, circumstances wherein one commanding officer has been replaced by another. Estonia's current regulation does not offer credible protection for the new superior with regard to criminal offences committed by the subordinates in the time preceding the latter superior taking over the relevant duties or ongoing offences that continue on from that time. ${ }^{* 6}$ Even when things are not stretched to such extremes, the absence of the condition that there have been failure to exercise control properly over subordinates allows censuring a superior for any failure to act, whether or not that failure carries real significance in relation to criminal offences committed by the subordinates and even when the superior has, in fact, been fulfilling his or her duties with due diligence and the crimes of the subordinates have taken place notwithstanding the reasonable and necessary measures taken by the superior. ${ }^{*} 67$

\subsection{Addressing non-suppression and non-reporting yet not covering non-prevention}

Art. 88 (1) of the PC foresees only two obligations of the superior: to repress a crime and to report on a crime already committed. ${ }^{*} 68$ According to international law, however, the duties of the superior comprise three distinct acts: to prevent, to repress, and to report. ${ }^{* 69}$ Prevention in that context involves the superior being expected to behave proactively and set in place mechanisms to avoid the possibility of offending

61 For a closer look at the causality involved, see also K. Ambos, 'Critical Issues in the Bemba Confirmation Decision', LJIL 22 (2009), p. 715, at pp. 721-722. - DOI: https://doi.org/10.1017/s0922156509990185. See also the Bemba decision (see Note 25), para 424.

62 Bemba (see Note 25), para 424.

63 Ibid., para 425.

64 K. Ambos, 'Critical Issues' (see Note 60), p. 722.

65 G. Mettraux, The Law of Command Responsibility (OUP 2009), p. 243. - DOI: https://doi.org/10.1093/acprof: oso/9780199559329.001.0001; R. Arnold, O. Triffterer, 'Responsibility of Commanders' (see Note 15), para 120.

66 Example: the decision on interlocutory appeal challenging jurisdiction in relation to command responsibility in the case Prosecutor v. Hadžihasanović, IT-01-47-AR72, A.Ch., 16.7.2003, para 45; see also discussion of that case, especially the dissenting opinions (relative to the majority finding), in the work of C. Greenwood, 'Command Responsibility and the Hadžihasanović Decision', JICJ 2 (2004), p. 598, at pp. 603-605. - DOI: https://doi.org/10.1093/jicj2.2.598.

67 G. Mettraux, The Law of Command Responsibility (see Note 64), pp. 244-245; C. Meloni, Command Responsibility (see Note 24), pp. 171-172.

68 One of the failures of the superior stipulated in Art. 88 (1) was originally formulated as 'ei ole takistanud kuriteo toimepanemist', where the English translation provided for this is 'failed to prevent the commission of the criminal offence'. I would contend that the above translation is incorrect. The original language of the norm refers not to a duty to prevent a criminal offence but to a duty to repress a commission of a crime that is already in progress.

69 R. Arnold, O. Triffterer, 'Responsibility of Commanders' (see Note 15), para 119; see also the Bemba judgment's (see Note 25) paragraphs 438 (on preventing), 439 (on repressing), and 440 (on punishing). 
- among others, a reporting obligation, monitoring, direct supervision, and a proper chain of command. ${ }^{*} 70$ This should be the 'first line of defence', and already dereliction of this duty, whereby it becomes possible for the subordinates to have a free hand to commit the crimes in the first place, has to be punishable. It has, therefore, been stressed in the literature, and rightly so, that later acts of repression or of simply submitting reports of the crimes to the appropriate authorities cannot exempt the superior from responsibility for having left his or her obligations unmet at a previous stage. ${ }^{*}{ }^{71}$ This lacuna in the text of Art. 88 (1) of the PC means that both disorderly behaviour of superiors and deliberate ignorance of - or even indifference to - predicted offences by the subordinates are currently rewarded by the Estonian legislator, as these fall outside the ambit of the domestic superior responsibility doctrine.

\subsection{The need to criminalise both reckless and intentional behaviour (along with negligent behaviour of military commanders)}

Yet another misconception has found its way into Art. 88 (1) of the Penal Code, relates to the mens rea required for there to be superior responsibility. According to Estonian law, it is necessary that the superior (in either a military or a non-military context) act with indirect intent (dolus eventualis) when failing in the duty to repress the crime of the subordinates or that the superior act with awareness ('olles teadlik' in Estonian parlance, hence dolus directus of the second degree) when failing to fulfil the duty to report a crime already committed. This is not the mens rea standard required for superior responsibility under international law. According to Art. 28 of the Rome Statute, the mental element required for military commanders is that these persons 'either knew or, owing to the circumstances at the time, should have known', while the standard for non-military superiors is 'either knew, or consciously disregarded information which clearly indicated [...]'. Although there is some debate in academic literature as to how exactly to interpret these standards, it is clear that at least for military superiors the standard is below the threshold of intention and should be understood as that of negligent behaviour. ${ }^{*} 72$ There is good reason to regard the standard required of a non-military superior as covering also non-intentional behaviour. ${ }^{*}{ }^{73}$

Here too, the issue is further complicated by the fact that, at base, all forms of liability have been packed together into Art. 88 (1) of the PC, because forms of conduct differ in their mental requirements. The nonpunishability of reckless and negligent dereliction of a superior's duties opens another avenue for opting out of responsibility to a superior who has arranged his or her relations with subordinates in a disorderly manner and who just does not care what is going on under his or her command. ${ }^{*} 74$ This lack of accountability also would facilitate a manner of action whereby it is useful for the superior to ignore even information that might point directly to misdeeds of his or her subordinates. When already acquainted with such information, the superior has obtained knowledge that could render him or her responsible as a superior, but not paying any attention to such information would eliminate the risk of legal liability.

70 W.J. Fenrick, 'Article 28: Responsibility of Commanders and Other Superiors', in O. Triffterer (ed.), Commentary on the Rome Statute of the International Criminal Court - Observers' Notes, Article by Article (Nomos 1999), para 9; see also the judgment in Prosecutor v. Bemba, ICC-01/05-01/08, T.Ch., 21.3.2016, paras 203-204.

71 In Blaškič, the trial chamber of the ICTY emphasised that the lack of preventing the commission of the crimes ex ante cannot be compensated for by punishing for them ex post; i.e., the superior is obliged to do both. Judgment in Prosecutor v. Blaškič, IT-95-14-T, T.Ch., 3.03.2000, para 336; see also Bemba (see Note 25), paras 436, 405.

72 See the further discussion of this by K. Ambos, Treatise (see Note 12), pp. 220-227, esp. p. 224 (dealing with military commanders) and pp. 227-228 (on non-military superiors).

73 According to K. Ambos (Treatise (see Note 12), p. 227), the mens rea standard for non-military superiors is conscious negligence. See also the following concurring opinions: G.R. Vetter, 'Non-military Superiors' (see Note 24) at p. 124; G. Fletcher, J.D. Ohlin, 'Reclaiming Fundamental Principles of Criminal Law in the Darfur Case', JICJ 3 (2005), p. 539, at p. 554. - DOI: https://doi.org/10.1093/jicj/mqi049. Objecting are A. Cassese, 'International Criminal Law' (2nd ed., OUP 2008), p. 66 et seq.; R. Cryer, Prosecuting International Crimes (Cambridge University Press 2005), pp. 324-325 (the latter nonetheless calling it, 'a clear and highly unfortunate retreat from the requirements of customary international law'). - DOI: https:// doi.org/10.1017/СBO9780511494161.

74 C. Meloni, Command Responsibility (see Note 24), p. 185. 


\subsection{The possibly misleading text of Art. 88's reference to crimes by subordinates only in conjunction with the superior's failure to submit a report on them}

Finally, the text of Art. 88 (1) of the PC is perplexing in that it mentions the responsibility of the superior only in conjunction with his or her failure to submit a report on subordinates' crimes. At the same time, in regard of failure to prevent the commission of a criminal offence, it remains unspecified whose crimes have to be prevented. This is troubling, since the whole point of the superior responsibility doctrine is to extend responsibility in respect of crimes committed by subordinated persons to their superiors because those superiors have failed to control their subordinates properly and to react appropriately as their powers permitted. ${ }^{*} 75$ Leaving this element implicit, at best, in the text, the legislator has created a remarkably vague situation. Of course, Art. 88 (1) still makes the superior's responsibility conditional to prevention of the criminal offence having been in that superior's power, but this reference alone is no substitute for specifying the superior-subordinate relationship. ${ }^{*} 76$ Prevention of a criminal offence might easily be within the power of a person in a superior position also in his or her relation with persons who do not fall under his or her authority as a superior. ${ }^{*} 77$ This is especially important in settings of civilian superior-subordinate relationships, because one person's position of superiority relative to another might not actually entail any real authority over the person holding the subordinate position. The responsibility of the superior must not be considered a vicarious responsibility - the link to the guilt principle has to remain clear and unquestionable also when a wrongdoing is attributed to a superior. ${ }^{*} 78$ For realisation of this, it is unavoidable that establishing the responsibility of the superior for dereliction of any of his or her duties must be made explicitly conditional to the commission of crimes on behalf of people truly subordinated to the superior. ${ }^{*} 79$

\section{Necessary amendments of the Estonian Penal Code}

From the analysis above, it appears that Estonian legislation on superior responsibility does not comply with the corresponding international norms, in several important respects. The deficits in Art. 88 (1) of the PC are of such a nature and extent that it is not possible to overcome them merely by adjusting the interpretation of the norm. Therefore, Estonia is not able to meet its international obligations for criminalisation linked to the responsibility of superiors. Estonia is especially unable to meet the standard set by Art. 28 of the Rome Statute and to comply with its obligation as a state party to the Rome Statute to foresee in its domestic legal order criminal responsibility for those responsible for international crimes. ${ }^{*} 80$ Hence, changes to Estonian regulation of the superior's responsibility are essential for bringing it into accordance with our international obligations and, specifically, to render the Estonian legal order able to prosecute and punish people who have committed acts punishable under the Rome Statute.

On the other hand, the way in which superior responsibility has been regulated in Art. 28 of the Rome Statute does not serve as a suitable role model for transposition into the Estonian domestic legal system

75 S. Boelaert-Suominen, 'Prosecuting Superiors' (see Note 29), p. 757; C. Meloni, 'Command Responsibility: Mode of Liability for the Crimes of Subordinates or Separate Offence of the Superior?', JICJ 5 (2007), p. 619, at p. 628. - DOI: https://doi. org/10.1093/jicj/mqm029; O. Triffterer, 'Command Responsibility, Article 28 Rome Statute: An Extension of Individual Criminal Responsibility for Crimes within the Jurisdiction of the Court - Compatible with Article 22, Nullum Crimen sine Lege?', in O. Triffterer (ed.), Gedächtisschrift für Theo Vogler (C.F. Müller Verlag 2004), p. 213, at p. 230; G. Mettraux, The Law of Command Responsibility (see Note 64), p. 81.

76 B. Burghardt, Die Vorgesetztenverantwortlichkeit im völkerrechtlichen Straftatsystem. Eine Untersuchung zur Rechtsprechung der internationalen Strafgerichtshöfe für das ehemalige Jugoslawien und Ruanda (Berliner Wissenschafts-Verlag 2008), p. 169. See also J. Bülte, Vorgesetztenverantwortlichkeit (see Note 33), p. 772.

77 As J. Bülte (ibid.) expresses it, otherwise superior responsibility could emerge whenever a person has power to give orders to someone even if only because of the short-term possibility of controlling that person, as with a hostage-taker' (p. 625).

78 Y. Ronen, 'Civilian Settings' (see Note 37) at p. 315, especially Note 8, with reference to further discussion.

79 O. Triffterer, "Command Responsibility" - Crimen sui Generis or Participation As "Otherwise Provided” in Article 28 Rome Statute?', in J. Arnold et al. (eds), Menschengerechtes Strafrecht. Festschrift für Albin Eser zum 70. Geburtstag (C.H. Beck 2005), p. 911.

80 See paras 4 and 6 of the preamble to the Rome Statute, affirming, respectively, that the most serious crimes of concern to the international community as a whole must not go unpunished and that their effective prosecution must be ensured by taking measures at the national level and by enhancing international co-operation. Also, recall every state party's duty to exercise its criminal jurisdiction over those responsible for international crimes. 
without major adjustments. The catch-all approach that the RS takes to the concept of superior responsibility has been criticised extensively by most commentators. The concept of superior responsibility has been stretched very far and wide in Art. 28 of the Rome Statute. It extends all the way from intentionally omitting to prevent or repress acts of the subordinates that one knew about in advance to merely not reporting acts of subordinates that the superior had no prior knowledge of. Also, it covers both intentional and negligent acts. Even more striking, however, is the fact that the responsibility of the superior is in no way differentiated among these - very different - sorts of omissions, and the superior is punishable for all such omissions in the same way as the actual perpetrator. The approach taken with the Rome Statute means that the superior's responsibility entails liability for negligence and intentional criminal offences alike. ${ }^{*} 81$ However, a superior who was unaware of the pending crimes of his or her subordinate cannot be punished as a wilful perpetrator of a crime. ${ }^{*}{ }^{2}$ An opposite approach would clearly not be compatible with the guilt principle, which underlies Estonian criminal law. ${ }^{*} 83$

Because of similar concerns, several countries have chosen a differentiated model for prescribing superior responsibility in their respective domestic statutes, wherein there are distinctive grounds of liability for particular categories of a superior's possible omissions. In the German Code of Crimes against International Law, superior responsibility has been divided into three parts. Firstly, superiors who do not avert crimes by their subordinates of which they had prior knowledge are punished in the same way as a perpetrator of the offence committed by those subordinates. If a superior either intentionally or negligently fails to exercise proper supervision of a subordinate under his or her command or under his or her effective control, that superior shall be punished for violation of the duty of supervision in the event that said subordinate commits an offence. This is formulated as a criminal offence sui generis, which occasions considerably less severe sanctions than an offence related to superior responsibility proper. Finally, a superior's mere failure to report to the responsible authorities on a crime previously unknown to him or her constitutes another sui generis criminal offence, punishable by less extreme sanctions still than either of the first two types of offence. ${ }^{* 84} \mathrm{~A}$ similar approach has been taken also by the Spanish ${ }^{* 85}$, Croatian ${ }^{* 86}$, Serbian ${ }^{* 87}$, Montenegrin $^{* 88}$, and Canadian ${ }^{* 89}$ legislators.

In line with the example of the legislation of the above-mentioned countries, one possible de lege ferenda option for the Estonian legislator would be to create three separate rules, covering the following omissions on the part of a superior: 1) intentionally not averting crimes of subordinates the imminent commission of which is known to the superior; 2) displaying intentional or negligent (reckless) disregard for the duty to supervise, where this results in crimes through the intentional failure to react; and 3) not reporting on crimes committed by subordinates. ${ }^{*} 90$ Because each of these scenarios involves its own distinctive level

81 G. Werle, 'Konturen eines deutschen Völkerstrafrechts. Zum Arbeitsentwurf eines Völkerstrafgesetzbuchs', Juristenzeitung 56/18 (2001), p. 891; W.A. Schabas, Genocide in International Law: The Crime of Crimes (Cambridge University Press 2000), pp. 305-306; also M. Neuner, 'General Principles' (see Note 21), p. 127.

82 See the explanations to the Government Draft Code of Crimes against International Law, p. 39.; M. Neuner (ibid.), pp. 127-128, with further reference to T. Weigend, 'Zur Frage eines ,internationalen“ Allgemeinen Teils' (see Note 21), p. 1397.

83 See discussion on that in German context: T. Weigend (ibid), p. 1397; also J. Bülte, Vorgesetztenverantwortlichkeit (see Note 33), p. 635. However, see the criticism described by B. Burghardt, 'Die Vorgesetztenverantwortlichkeit nach Völkerstrafrecht und deutschem Recht (§ 4 VStGB)', ZIS 10 (2010), p. 695, at p. 702 et seq.

84 See 'Völkerstrafgesetzbuch vom 26. Juni 2002' (BGBl I 2254, BGBl I 3150), articles 4 (on the responsibility of military commanders and other superiors), 14 (on violation of the duty of supervision), and 15 (on omission of reporting a crime).

85 See 'Ley Orgánica 10/1995, de 23 de noviembre, del Código Penal', Art. 615bis. Available at https://www.boe.es/eli/es/ lo/1995/11/23/10/con, last visited on 10.2.2019.

86 See the Criminal Code of the Republic of Croatia, Art. 96. Available at http://www.mvep.hr/files/file/dokumenti/prevodenje/ zakoni/kazneni-zakon-nn-125-11-eng.pdf, last visited on 7.2.2019.

87 See the Criminal Code of the Republic of Serbia, Art. 332 (on failure to report) and Art. 384 (on the responsibility of the superior. Available at https://www.legislationline.org/documents/section/criminal-codes/country/5/Serbia/show, last visited on 7.2.2019.

88 See the Criminal Code of the Republic of Montenegro, specifically Art. 386 (on failure to report) and Art. 440 (on responsibility of the superior). Available at https://www.legislationline.org/documents/section/criminal-codes/country/57/Montenegro/ show, last visited on 7.2.2019.

89 See the Crimes against Humanity and War Crimes Act, sections 5 and 7. Available at https://laws-lois.justice.gc.ca/ PDF/C-45.9.pdf, last visited on 7.2.2019.

90 The Penal Code could be amended accordingly:

1) Art. 88 Superior responsibility

A military commander or a civilian superior who omits to prevent subordinates under his or her effective command and control from committing a criminal offence pursuant to this chapter shall be punished in addition to the principal offender. 
of gravity of the superior's omissions ${ }^{*} 91$, there should exist a sanctioning frame that is distinctive to each of them, accordingly. ${ }^{*} 92$

\section{Conclusions}

States parties to the Rome Statute have to make sure that their domestic criminal statutes enable prosecution of persons suspected of having committed crimes listed in articles 6-8bis of the Rome Statute. Moreover, states parties also need to be cautious with regard to the compliance of the general principles of criminal responsibility in their domestic criminal codes with the standards set in Part 3 of the Rome Statute. While, for the most part, compliance does not pose a big problem, because domestic criminal statutes and legal dogmatics are far more advanced in regulating most of the 'general part' issues than is the Rome Statute, there remain cases in which this might not be so: there are institutes of the general part of criminal law that are unique to the domain of international law and usually either not addressed at all in domestic law or given only rudimentary treatment therein. One such institute, an original creation of international law, is the concept of superior responsibility. If a domestic criminal-law system is to be equipped to operate in conformity with the underlying idea of complementarity that is among the ICC's underpinnings, it is vital that, amongst other aspects, the superior responsibility doctrine be transposed into domestic law properly.

As demonstrated above by the deconstruction of Art. 88 (1) of the Estonian Penal Code, stipulating the superior responsibility concept in the Estonian legal system, there are considerable differences between the Estonian regulation and customary international law on superior responsibility or Art. 28 of the Rome Statute. When one analyses the differences of Estonian law from international norms, it appears that there are several respects in which Estonian regulation does not meet the international standard and, hence, large lacunae are to be found in Estonian law on superior responsibility. For this reason, it is recommended that Estonian regulation of superior responsibility be complemented in such a way that it is consistent with international law - specifically, with the requirements of Art. 28 of the Rome Statute - while simultaneously taking into consideration the demands stemming from Estonian criminal-law dogmatic, especially the guilt principle.

2) Art. 88-1 Violation of the duty of supervision

(1) Intentional failure of a military commander to exercise control properly over subordinates under his or her effective command and control, if the subordinates commit a criminal offence addressed in this chapter and if that commander should have known about the imminent commission of such criminal offence and could have prevented or repressed it, is punishable by up to five years' imprisonment.

(2) Intentional failure of a civilian superior to exercise control properly over subordinates under his or her effective command and control, if the subordinates commit a criminal offence covered by this chapter and if the superior consciously disregarded information that clearly was indicative of imminent commission of such criminal offence and he or she could have prevented or repressed it, is punishable by up to five years' imprisonment.

(3) The acts described in the subsections ( 1 and 2) of this section are, when committed with negligence, punishable by up to three years' imprisonment.

3) Art. 88-3 A superior's failure to report a crime

Failure of a military commander or a civilian superior to submit, without undue delay, a report of a criminal offence covered by this chapter that has been committed by a subordinate under his or her effective command and control is punishable by up to five years' imprisonment.

91 T. Weigend, Bemerkungen (see Note 32), pp. 1025-1026.

92 K. Ambos, Internationales Strafrecht (see Note 36), §7, para 59. 